\title{
Assessment of surface water quality of inland valleys for cropping in SW Nigeria
}

\author{
O. S. Aboyeji ${ }^{1}$ O. O. Ogunkoya ${ }^{2}$
}

Received: 19 January 2015/ Accepted: 23 June 2015/Published online: 7 July 2015

(c) The Author(s) 2015. This article is published with open access at Springerlink.com

\begin{abstract}
Inland valley agro-ecosystems which are a category of wetlands have potential for sustainable crop production relative to uplands. A major challenge to their utilisation in the study area is their heterogeneity in hydrology, morphology, soil types and agro-economy. The study assessed the surface water quality of three typologies of the agro-ecosystems-amphitheatre-like valley-heads (Am), valley-side (VS), and low depression (LD)—for cropping. Surface water of six sites were sampled during the wet and dry seasons. The physicochemical properties and metal concentrations of the samples were analysed. Descriptive statistics and water quality indices were used to assess the suitability of the waters of the agro-ecosystems for cropping. Results showed that the valleys have neutral to slightly alkaline waters. Values of physicochemical parameters are generally within the acceptable range for cropping. The concentration of major cations varied across the inland valley types, but exhibited similar characteristics within each valley. The dominance of the major cations is in the order of $\mathrm{Na}>\mathrm{Ca}>\mathrm{K}>\mathrm{Mg}$. ANOVA results indicated that there is no significant difference in the concentration of heavy metals across the valleys $(F=2.044, p=0.138, \alpha=0.05)$. Generally, most of the physicochemical parameters and trace metals have low concentrations and are non-toxic to plants. Values of water quality indices (sodium adsorption ratio, soluble sodium percentage, total dissolved solids and permeability index)
\end{abstract}

O. S. Aboyej

olatunjiaboyeji@yahoo.com

1 Regional Centre for Training in Aerospace Surveys (RECTAS), Ile-Ife, Osun State, Nigeria

2 Department of Geography, Obafemi Awolowo University, Ile-Ife, Osun State, Nigeria indicated that the concentrations of minerals in waters across the valley typologies are generally within permissible limits for cropping.

Keywords Inland valley · Irrigation - Wetland · Water quality indices · Agriculture · Food security

\section{Introduction}

Sustainable socioeconomic development is rarely attainable without adequate development of water resources to support food production, industry, environment and other human needs. However, a major challenge to provision of safe water for various demands is the deteriorating quality of existing water resources. An understanding of the physical, chemical and biological properties of water is crucial before it's usage for given purposes. With specific reference to cropping, water of appropriate quality facilitates better crop yields under optimal soil and water management conditions. However, as water always contains some amounts of soluble salts depending on the source of the water and the media through which it flows, it is imperative that the quality of water is assessed against the type of crop that it will be used to irrigate (Mukherjee et al. 2005).

In the study, a major challenge area is food insecurity partly caused by inadequate agricultural productivity (Aboyeji and Ogunkoya 2014; Ike 2012; Ogunremi et al. 2000). Food production in southwest Nigeria traditionally occurs on upland ecosystems through rain-fed cultivation. The major means of sustaining soil fertility in this region is through bush-fallowing and application of fertilisers-domestic waste, animal manure and inorganic fertilisers. However, due to population pressure and the intensifying 
demand for food, fallow periods are being shortened, and the need to cultivate the more fragile uplands and marginal lands is becoming heightened (Andriesse et al. 1994; Ogunremi et al. 2000; Thenkabail and Nolte 1995). An approach that can be used to mitigate these challenges is sustainable use of low acreage wetlands which are ubiquitous in the study area (Ogban and Babalola 2009; Ogunremi et al. 2000; Thenkabail and Nolte 1996; Windmeijer and Andriesse 1993). These wetlands, referred to as 'inland valleys', and locally as 'fadama', and 'akuro', generally occur in the lower slopes of the toposequence or where an impermeable soil layer retards percolation (Windmeijer and Andriesse 1993).

The morphology of inland valleys is an important feature determining their characteristics, functioning and utilisation. For example, the soil drainage and flooding regimes of inland valleys are influenced by the shape of the valley (Windmeijer and Andriesse 1993). In southwest Nigeria, three typologies of inland valleys are commonly found-amphitheatre-like valley-heads, valley-side inland valleys and low depression inland valleys (Aboyeji 2013). The amphitheatre-like types are valley heads, commonly found on higher elevations where they mark the emergence of rivers. They are typically concave in profile with fairly flat but relatively narrow valley floors. Some may contain a stream at the centre with fringes containing saturated soils for most part of the year, while others may be without a well-defined stream channel (see Fig. 1). The morphology and soils are dominated by colluvial processes (Raunet 1985). The valley-side inland valleys occur on lower slopes down slope of the valley-head types. They consist of a wider valley section with side slopes relatively gentler, ranging from convex to concave. The almost flat valley bottoms always contain shallow stream channels (see Fig. 1). Though some river flooding and associated sedimentation may occur, the morphology and soils are dominated by colluvial processes. The low depression inland valleys are typically found on gently undulating terrains. The side slopes are relatively low and concave with fairly flat valley floor (Fig. 1). They occur along ephemeral or perennial streams and seasonally flooded.

In spite of the abundance of the inland valley agroecosystems in southwest Nigeria, their potential for crop production has not been fully exploited because they are heterogeneous in morphology, soil types, vegetation, hydrology and agro-economy (Buri et al. 1999; Ogunremi et al. 2000). There is limited information on their detailed specific characteristics that could enable their identification for specific agricultural utilisation (Fagbami and Ajayi 1990; Ogban and Babalola 2003). In the literature, little is known about the irrigation quality of surface water of inland valleys of the study area, though there have been studies on the water quality of other surface and
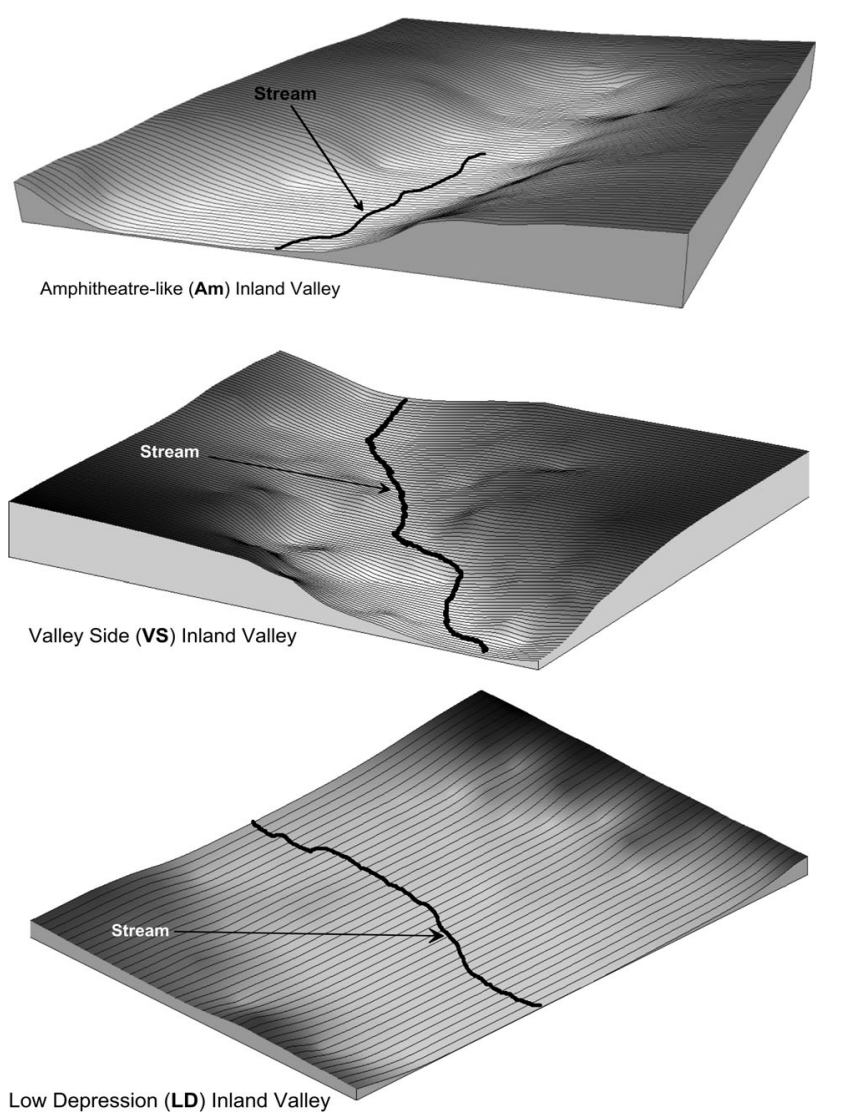

Fig. 1 Typologies of inland valleys in the study area: amphitheatrelike valley-head, valley-side inland valley and low depression inland valley

groundwaters. Thus, Ogunkoya and Adejuwon (1990) studied the water chemistry of some rivers draining the basement complex in SW Nigeria and found that the water chemistry of the rivers reflects the chemistry and susceptibility to weathering of rocks drained by the rivers. Ogunfowokan et al. (2009) and Ogunfowokan et al. (2013) assessed the chemical quality of three streams under different land systems in Obafemi Awolowo University IleIfe, SW Nigeria and observed that levels of physicochemical parameters including trace metals depended on the type of agricultural inputs and practices in the three catchments studied. They also concluded that water samples from the three streams did not exhibit toxicity problems in relation to salinity and sodium hazard. Awomeso et al. (2010) determined the hydrochemical characteristics of six springs in Oke-Igbo community of Ondo State, SW Nigeria. They found that the spring waters generally ranged from slightly acidic to acidic water types. Though these studies provide information on surface water chemistry in some parts of south-western Nigeria, the information may not be representative of those of specific types of inland valleys that comprise swamps and marshes. Apart from 
this, the flooding regime of some of the valleys is very short, making dry season farming difficult or impossible. To farm during the dry seasons, farmers sometimes make impoundments across streams or divert channel waters to reservoirs constructed close to the channel, to water crops like vegetables and cereals. This study therefore assessed the quality of surface water of three common typologies of inland valley agro-ecosystem of the study area for cropping.

\section{Materials and methods}

\section{Description study area and sampling sites}

Six inland valley agro-ecosystems which belong to the three typologies commonly found south-western Nigeria were investigated. These are sites Am1 and Am2 (amphitheatre-like valley-heads), sites VS1 and VS2 (valleyside inland valleys) and sites LD1 and LD2 (low depression inland valleys) (see Fig. 2; Table 1). The area of the valley bottom in each of the inland valley types ranges between 1690 and $5723 \mathrm{~m}^{2}, 25,477$ and $28,547 \mathrm{~m}^{2}$ and 17,065 and $30,004 \mathrm{~m}^{2}$ for amphitheatre-like, valley side and low depression inland valley types, respectively. The slopes of the valley floor of the Am valleys range from $0^{\circ}$ to $5^{\circ}$, VS from $0^{\circ}$ to $2^{\circ}$ and the $\mathrm{LD}$ types from $0^{\circ}$ to $0.5^{\circ}$. These sites are located within latitudes $7^{\circ} 57^{\prime}-8^{\circ} 14^{\prime}$ north and longitudes $4^{\circ} 41^{\prime}-4^{\circ} 58^{\prime}$ east, around the southern foothills of the topographic zone referred to as the Yoruba Hills, in south-western Nigeria (see Fig. 2). Underlain by Basement Complex rocks comprising granites, variously migmatized granite-gneisses, and schists, the terrain of the study area consists of plains studded with granite and granite-gneiss inselbergs. The highland features constitute the watersheds, while the denudational landscape through which rivers flow northwards or westwards to form tributaries of the River Niger constitutes the plains.

The climate of the study area belongs to Koppen's $A_{\mathrm{w} 1}$ Tropical Wet and Dry type. It is characterised by a dry season extending from November to March and a wet season extending from April to October. The annual mean temperature and mean annual rainfall are about $26^{\circ} \mathrm{C}$ and $1300 \mathrm{~mm}$, respectively, with 102 rain days. The rainy season is bimodal, with a short period of limited rainfall occurring between July and August each year.

The soils of the study area are Ferruginous Tropical Soils derived from Basement Complex rocks. The character of the soils is a function of the underlying parent materials, the climate, which is characterised by a marked rainfall seasonality and the woodland vegetation type (Aboyeji and Ogunkoya 2014). According to Food and Agricultural Organisation (FAO) soil taxonomy legends, the soils consist of Lixisols (36.16\%), Lixisols/Regosols $(36.47 \%)$ and Acrisols/Regosols $(27.37 \%)$. The main economic activities of the people are agriculture and trading. The agricultural practice is characterised mainly by subsistence small holder farming practiced in upland areas. Food crops grown include maize, cassava, plantain/ banana, vegetables, rice and yams. In some places mango, cashew, cocoa, oil palm, cola are grown in plantations.

\section{Sample collection and analysis}

Five sets of surface water samples were collected from defined channels of each inland valley. The samples were collected in the middle of the months of May 2011, August 2011, November 2011, January 2012 and March 2012. These months were selected to cover the period when rain begins to be well established (May) through to the hydrological peak of dry season (March/April of the following year) in the study area. Two samples were collected in each site at preselected locations within the central channel (one each from upstream and downstream). Complete samples could not be collected at LD valleys because channel waters dried up at some points during the dry months (from November 2011 in LD1 and February 2012 in LD2). Samples were collected in prerinsed plastic bottles. Before a sample was collected at a location, the container attached to the sampler and the bottle used to store the water were rinsed with the water collected at the location. The bottles were kept in a chilled box while being transported to the laboratory for analysis. The $\mathrm{pH}$ and electrical conductivity (EC) at each sampling point were measured in situ. Chemical analyses of the water samples were carried out at the laboratory of the Department of Soil Science, Obafemi Awolowo University, Ile-Ife, Nigeria. Each water sample was analysed for calcium $\left(\mathrm{Ca}^{2+}\right)$, magnesium $\left(\mathrm{Mg}^{2+}\right)$, potassium $\left(\mathrm{K}^{+}\right)$and sodium $\left(\mathrm{Na}^{+}\right)$, using Flame photometer, while the anions $\left(\mathrm{CO}_{3}{ }^{2-}, \mathrm{HCO}_{3}{ }^{-}, \mathrm{Cl}^{-}\right.$and $\left.\mathrm{SO}_{4}{ }^{2-}\right)$ were analysed titrimetrically as described in Page et al. (1982). Iron $(\mathrm{Fe})$, copper $(\mathrm{Cu})$, zinc $(\mathrm{Zn})$, lead $(\mathrm{Pb})$, nickel (Ni), were analysed using atomic absorption spectrometry (AAS).

The quality of the surface waters of the inland valleys for agricultural utilisation was assessed using major water quality indicators. Descriptive statistics and analysis of variance (ANOVA) were used to analyse the differences in values of water quality indicators within and between the valley types. The water quality indices considered include sodium adsorption ratio (SAR), soluble sodium percentage (SSP), total dissolved solids (TDS) and permeability index (PI). These were obtained as follows:

1. Sodium adsorption ratio (SAR) was calculated using the following formula (Wallender and Tanji 2012): 


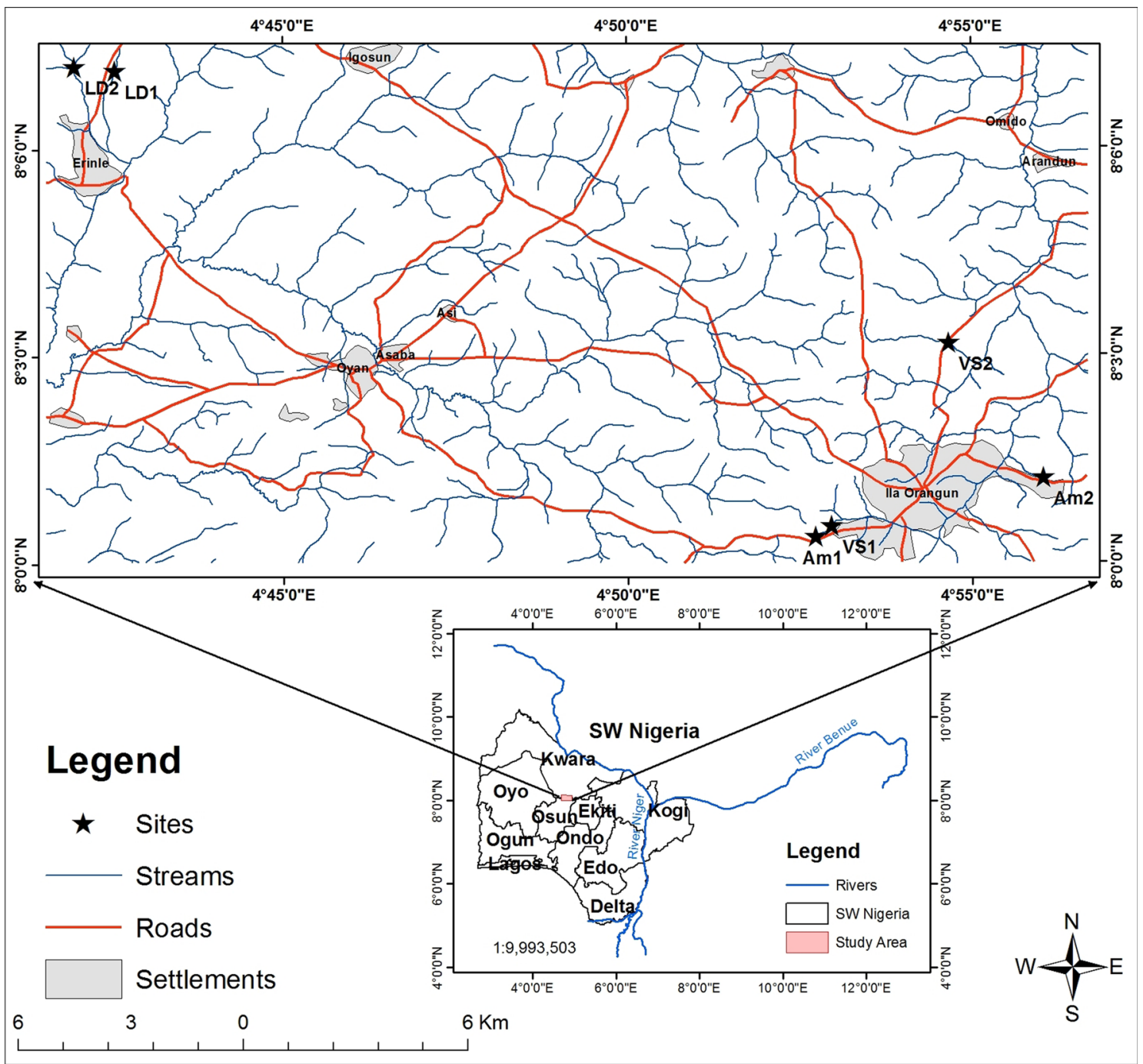

Fig. 2 The study area (Aboyeji and Ogunkoya 2014)

Table 1 Location of sampling points in the three typologies of inland valleys studied

\begin{tabular}{llllll}
\hline Number & Sampling location & Eastings & Northings & Elevation $(\mathrm{m})$ & Valley type \\
\hline 1 & Am1a & 707,099 & 885,437 & 507.9 & Amphitheatre-head inland valley \\
2 & Am1b & 707,140 & 885,471 & 498.8 & Amphitheatre-head inland valley \\
3 & Am2a & 713,148 & 887,021 & 519.7 & Amphitheatre-head inland valley \\
4 & Am2b & 713,122 & 887,038 & 482.5 & Amphitheatre-head inland valley \\
5 & VS1a & 707,493 & 885,728 & 499 & Valley-side inland valley \\
6 & VS1b & 707,473 & 885,698 & 497.2 & Valley-side inland valley \\
7 & VS2a & 710,656 & 890,593 & 461.8 & Valley-side inland valley \\
8 & VS2b & 710,609 & 890,615 & 461.3 & Valley-side inland valley \\
9 & LD1a & 687,306 & 897,881 & 391.6 & Low-slope depression inland valley \\
10 & LD1b & 687,313 & 897,952 & 378.6 & Low-slope depression inland valley \\
11 & LD2a & 688,330 & 897,850 & 425.3 & Low-slope depression inland valley \\
12 & LD2b & 688,315 & 897,824 & 400.8 & Low-slope depression inland valley \\
\hline
\end{tabular}


$\mathrm{SAR}=\frac{\mathrm{Na}^{+}}{\sqrt{\left(\frac{\mathrm{Ca}^{2+}+\mathrm{Mg}^{2+}}{2}\right)}}$

where all the ions are expressed in milligram equivalents per litre (meq/L);

2. Soluble Sodium Percentage (SSP) was calculated according to the equation below (Todd and Mays 2005).

$S S P=\frac{\mathrm{Na}^{+} \times 100}{\mathrm{Na}^{+}+\mathrm{Ca}^{+}+\mathrm{Mg}^{+}+\mathrm{K}^{+}}$

where all the ions are expressed in meq/L;

3. Total dissolved solids (TDS) were estimated from their specific conductance values by multiplying with a factor of 0.64 (i.e. TDS $(\mathrm{mg} / \mathrm{l})=\mathrm{EC}(\mu \mathrm{S} / \mathrm{cm}) \times 0.64)$ which is taken as the conversion factor for most natural waters (Wallender and Tanji 2012);

4. Permeability Index (PI) was calculated according to Doneen (1964) by the following equation.

$\mathrm{PI}=\frac{\mathrm{Na}^{+}+\sqrt{\mathrm{HCO}_{3}^{-}}}{\mathrm{Ca}^{2+}+\mathrm{Mg}^{2+}+\mathrm{Na}^{+}} \times 100$

where, all the ions are expressed in meq/L.

Results derived from the application of these indices to water quality data were subjected to descriptive analysis and compared with known or stipulated standards.

\section{Results and discussion}

Figures 3 shows the pattern of $\mathrm{pH}$ in the six inland valleys. Based on the valley typology, the $\mathrm{pH}$ values ranged from an average of 5.88-7.87, 6.54-7.87 and 6.31 in Am, VS and LD valley types, respectively. Values obtained from wet season samples were generally lower than those of the dry season. The lowest and highest individual values of 5.70 and 7.87 were recorded in November (LD1) and
January (VS1), respectively. The waters were generally slightly acidic (Am1: 5.88) to slightly alkaline (LD1: 7.4) at the beginning of the rainy season, and slightly acidic (Am1: 6.13) to moderately alkaline (VS1: 7.88) towards the peak of dry season. These values were within the permissible limit for irrigated agriculture water $\mathrm{pH}$ of $6.0-8.5$ (Ayers and Westcot 1994; Bauder et al. 2014). Hence, the surface waters of inland valleys of the study area can be considered to be general good for recession agriculture. ANOVA results indicate that differences exist in the concentration of $\mathrm{pH}$ along valley typologies $(F=6.68$, $p=0.005, \alpha=0.05)$. The result is similar to those reported by Ogunkoya and Adejuwon (1990); Jaji et al. (2007) and Ayeni et al. (2011) who found a mean range of 6.8-8.0, 6.9-7.9 and 6.1-8.1, respectively, in studies conducted in parts of south-western Nigeria.

The pattern of mean Electric Conductivity (EC) values for Am, VS and LD valley types is depicted in Fig. 4. EC provides a measure of the amount of total dissolved solids (TDS) or salinity in the water. The chemicals contributing substantially to the total dissolved solids are sodium, calcium, magnesium, chloride, sulphate, and bicarbonate. According to Bauder et al. (2014), the higher the EC, the less water is available to plants, even though the soil may appear wet. Because plants can only transpire 'pure' water, hence usable plant water in the soil solution decreases dramatically as EC increases. As the amount of water transpired through a crop is directly related to yield, irrigation water with high EC reduces yield potential (Bauder et al. 2014). The mean EC ranged from $0.03 \mathrm{dS} / \mathrm{m}$ for $\mathrm{Am}$ through $0.07 \mathrm{dS} / \mathrm{m}$ in VS to $0.23 \mathrm{dS} / \mathrm{m}$ in LD valleys. The lowest individual value of $0.03 \mathrm{dS} / \mathrm{m}$ was recorded in $\mathrm{Am} 1$ (November) while the highest value of $0.67 \mathrm{dS} / \mathrm{m}$ was obtained in VS1 (March). The value of coefficient of variation $(\mathrm{CV})$ ranged between 0.50 and 0.63 , indicating that the EC of surface water in channels is variable in distribution across the inland valleys studied. Analyses of the differences in values along valley types using ANOVA
Fig. 3 Pattern of mean $\mathrm{pH}$ values for Am, VS and LD valley types

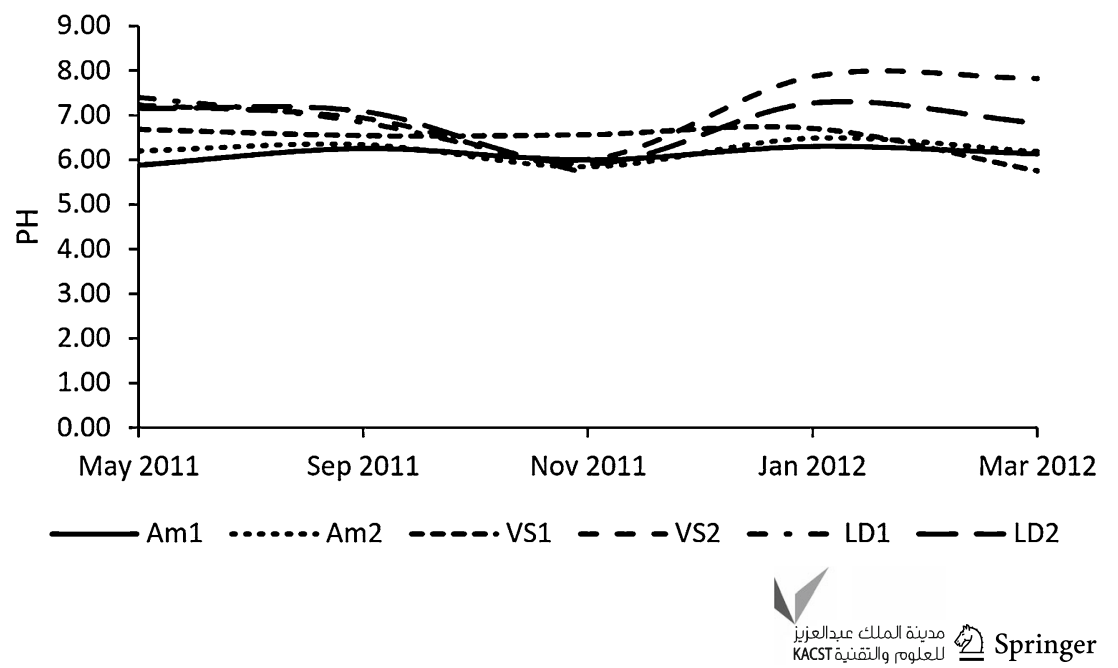




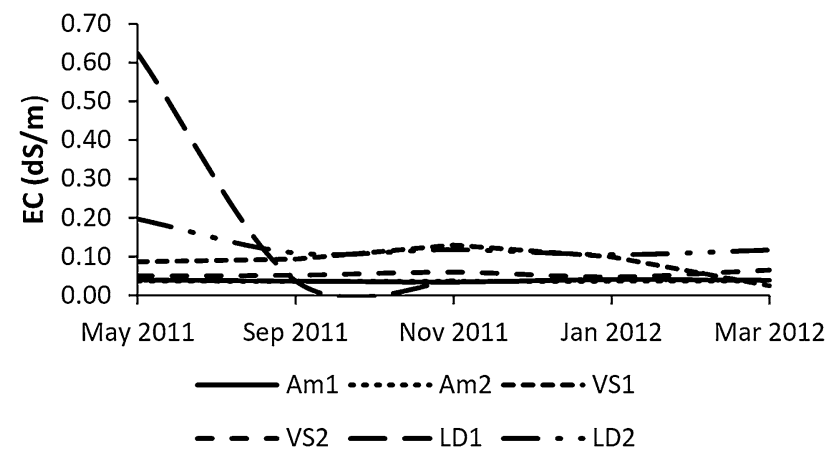

Fig. 4 Pattern of mean electric conductivity (EC) values for Am, VS and $\mathrm{LD}$ valley types

indicate that at $\alpha=0.05$ significant differences exist $(F=4.30, p=0.025)$. EC values obtained from all the water samples fall mainly within low saline type (cf. Table 2), when measured along the suitability rating scale provided by Fipps (2003). The EC values are within the range of values reported for rivers in the same region (Ogunfowokan et al. 2013; Talabi and Tijani 2013), and may suggest that the conductivities of waters of the inland valleys reflect the rock and soil mineralogy, and the degree of weathering in the respective catchments. Also, the lower conductivity values obtained in wet season samples reflect the dilution effect of rainfall. According to Wilcox (1955), conductivities of less than $0.20 \mathrm{dS} / \mathrm{m}$ are permissible for irrigation. Thus, the results indicate that waters of the inland valleys are generally safe for irrigational purposes.

The results of major cations content and their variation in the six sites for May 2011, September 2011, November 2011, January 2012, and March 2012 are presented in Table 3. Apart from the LD valleys which dried up during the dry season, there was water in other valley types throughout the year. The concentrations varied across the valley types but exhibited similar patterns within each valley. The concentration of sodium ion $\left(\mathrm{Na}^{+}\right)$in meq/l varied from 0.08 to $0.13,0.07$ to $0.13,0.09$ to $0.20,0.09$ to $0.99,0.14$ to 0.50 and 0.16 to 0.84 in Am1, Am2, VS1, VS2, LD1 and LD2 valleys, respectively. Averages for the $\mathrm{Am}, \mathrm{VS}$ and LD valley types were $0.13,0.60$ and $0.67 \mathrm{meq} / \mathrm{l}$, respectively, while the $\mathrm{CV}$ ranged from 0.21 to 1.27 , indicating a high variability across the valley types. The concentration of $\mathrm{K}^{+}$(meq/l) in Am1, Am2, VS1, VS2, LD1 and LD2 valleys ranged from 0.03 to $0.05,0.04$ to $0.05,0.03$ to $0.06,0.07$ to 0.28 and 0.08 to 0.60 , respectively. Mean values for inland valley types were $0.05,0.17$ and 0.47 for Am, VS and LD valleys, respectively. The CV ranged from 0.122 to 1.09 . The values of $\mathrm{Ca}^{2+}$ (in meq/l) were generally low in all the sites, with concentrations below detection level in many of the samples, particularly in Am and VS valley types. The mean values were 0.01 , 0.06 and 0.33 for Am, VS and LD valleys, respectively. $\mathrm{The}^{\mathrm{Mg}}{ }^{2+}$ (in meq/l) in water samples ranged between 0.02

Table 2 Classification of water quality indicators for irrigational Classification of water quality indicators for irrigational use [extended from Fipps (2003), Richards et al. (1954), Wilcox (1955) and Robinove et al. (1958)]_ENREF_23

\begin{tabular}{|c|c|c|c|}
\hline Index & Classification & Range & $\%$ of sample \\
\hline \multirow[t]{4}{*}{ Total dissolved solids $(\mathrm{mg} / \mathrm{l})$} & Non-saline & $<1000$ & 100 \\
\hline & Slightly Saline & $1000-3000$ & 0 \\
\hline & Moderately saline & $3000-10,000$ & 0 \\
\hline & Very saline & $>10,000$ & 0 \\
\hline \multirow[t]{5}{*}{ SSP (\%) } & Excellent & $<20$ & 0 \\
\hline & Good & $20-40$ & 48 \\
\hline & Permissible & $40-60$ & 44 \\
\hline & Doubtful & $60-80$ & 8 \\
\hline & Unsuitable & $>80$ & 0 \\
\hline \multirow[t]{4}{*}{ SAR (meq/l) } & Excellent & $<10$ & 100 \\
\hline & Good & $10-18$ & 0 \\
\hline & Doubtful & $18-26$ & 0 \\
\hline & Unsuitable & $>26$ & 0 \\
\hline \multirow[t]{6}{*}{$\mathrm{EC}(\mathrm{dS} / \mathrm{m})$} & Low saline & Below 0.25 (totally save) & 96 \\
\hline & Moderately saline & $0.25-0.75$ (save for all conditions) & 4 \\
\hline & Medium to high salinity & $0.75-2.25$ (save only with permeable soils and moderately leaching) & 0 \\
\hline & High salinity & $2.25-4.0$ (unsafe) & 0 \\
\hline & Very high salinity & $4.0-6.0$ (unsafe) & \\
\hline & Excessive salinity & Above 6.0 (unsafe) & 0 \\
\hline
\end{tabular}


Table 3 Summary statistics of physicochemical properties of surface water of the study area

\begin{tabular}{|c|c|c|c|c|}
\hline Index & Inland valley & Minimum & Maximum & Mean \\
\hline \multirow[t]{6}{*}{$\mathrm{pH}$} & Am1 & 5.88 & 6.30 & 6.14 \\
\hline & Am2 & 6.20 & 7.31 & 6.59 \\
\hline & VS1 & 6.15 & 6.84 & 6.57 \\
\hline & VS2 & 6.96 & 7.87 & 7.43 \\
\hline & LD1 & 6.84 & 7.40 & 7.21 \\
\hline & LD2 & 6.31 & 7.27 & 6.93 \\
\hline \multirow[t]{6}{*}{$\mathrm{EC}(\mathrm{dS} / \mathrm{m})$} & Am1 & 0.03 & 0.04 & 0.04 \\
\hline & $\mathrm{Am} 2$ & 0.04 & 0.04 & 0.04 \\
\hline & VS1 & 0.09 & 0.11 & 0.09 \\
\hline & VS2 & 0.05 & 0.07 & 0.05 \\
\hline & LD1 & 0.04 & 0.62 & 0.24 \\
\hline & LD2 & 0.11 & 0.20 & 0.13 \\
\hline \multirow[t]{6}{*}{$\mathrm{Na}^{+}(\mathrm{meq} / \mathrm{l})$} & Am1 & 0.08 & 0.13 & 0.11 \\
\hline & Am2 & 0.07 & 0.13 & 0.09 \\
\hline & VS1 & 0.09 & 0.20 & 0.13 \\
\hline & VS2 & 0.09 & 0.99 & 0.30 \\
\hline & LD1 & 0.11 & 0.50 & 0.25 \\
\hline & LD2 & 0.16 & 0.84 & 0.48 \\
\hline \multirow[t]{3}{*}{$\mathrm{Ca}^{2+}(\mathrm{meq} / \mathrm{l})$} & VS2 & 0.05 & 0.90 & 0.48 \\
\hline & LD1 & 0.10 & 0.80 & 0.45 \\
\hline & LD2 & 0.10 & 0.50 & 0.26 \\
\hline \multirow[t]{5}{*}{$\mathrm{K}^{+}(\mathrm{meq} / \mathrm{l})$} & Am1 & 0.03 & 0.05 & 0.04 \\
\hline & VS1 & 0.03 & 0.06 & 0.04 \\
\hline & VS2 & 0.07 & 0.28 & 0.14 \\
\hline & LD1 & 0.08 & 0.60 & 0.26 \\
\hline & LD2 & 0.16 & 0.84 & 0.48 \\
\hline \multirow[t]{6}{*}{$\mathrm{Mg}^{2+}(\mathrm{meq} / \mathrm{l})$} & Am1 & 0.02 & 0.13 & 0.08 \\
\hline & $\mathrm{Am} 2$ & 0.04 & 0.13 & 0.09 \\
\hline & VS1 & 0.08 & 0.26 & 0.16 \\
\hline & VS2 & 0.07 & 0.47 & 0.19 \\
\hline & LD1 & 0.15 & 2.19 & 0.86 \\
\hline & LD2 & 0.11 & 0.73 & 0.33 \\
\hline
\end{tabular}

$A m$ amphitheatre-head inland valley, $V S$ valley-side inland valley, $L D$ low-slope depression inland valley

and $0.13,0.04$ and $0.13,0.08$ and $0.26,0.07$ and $0.47,0.23$ and 2.19 and 0.11 and 0.73 in Am1, Am2, VS1, VS2, LD1 and LD2 valleys, respectively. The concentrations were highest in LD valleys and lowest in Am valley types.

The concentration of cations in the water of the study area is in the order of $\mathrm{Na}^{+}>\mathrm{Ca}^{2+}>\mathrm{K}^{+}>\mathrm{Mg}^{2+}$, with values far below the WHO recommended limit of $200 \mathrm{mg} / \mathrm{l}$ for drinking water (WHO 2011) and non-toxic to plants. Results obtained for the inland valleys studied are comparable to those reported by earlier researches in the region (e.g. Ige et al. (2008) and Awomeso et al. (2010)). For example, Awomeso et al. (2010) reported in water samples obtained from springs in Oke-Igbo, southwest Nigeria, the hydrochemical characteristics indicated that $\mathrm{Na}^{+}, \mathrm{K}^{+}$, $\mathrm{Ca}^{2+}, \mathrm{Mg}^{2+}$ and $\mathrm{HCO}_{3}{ }^{-}$ranged 2-6, 1-3, 0.99-2.84, $1.34-3.65$ and $24.4-73.3 \mathrm{meq} / \mathrm{l}$, respectively.

Iron is a vital trace element in soils that plays important role in plant respiratory and photosynthetic reactions (Bennett 1993). The mean concentration of Iron $(\mathrm{Fe})$ in water samples ranged from $0.08 \mathrm{mg} / \mathrm{l}$ in LD1 to $8.83 \mathrm{mg} / \mathrm{l}$ in VS1 (Table 4). The high concentration of Fe in some of the samples can be attributed to the type of bedrock and anthropogenic activities around the area. Nickel (Ni) is required by plants for proper seed germination. Its toxicity decreases with an increase in $\mathrm{pH}$, with acidic soil being most sensitive (Pratt and Suarez 1990). The concentration of nickel $(\mathrm{Ni})$ in the water samples ranged from 0.01 to $0.07 \mathrm{mg} / \mathrm{l}$. The values obtained are similar to those reported by Eni and Efiong (2011) and Odukoya et al. (2013) in their respective works in parts of southern Nigeria. According to Pratt and Suarez (1990), Ni value of $0.20 \mathrm{mg} /$ 1 is the recommended maximum level. At concentration values ranging $0.5-1.0 \mathrm{mg} / \mathrm{l}, \mathrm{Ni}$ is toxic to many plants. Zinc ( $\mathrm{Zn}$ ) concentration in water samples varied from 0.02 (LD1) to $0.9 \mathrm{mg} / \mathrm{l}$ (VS1). All samples had concentrations well below the WHO (2011) recommended concentration value of $3 \mathrm{mg} / \mathrm{l}$ for portable water. $\mathrm{Zn}$ is needed by plants for growth hormone production. High concentration of $\mathrm{Zn}$ is toxic to most forms of plants and aquatic animals. It can cause gastrointestinal disturbance in man if high concentration is injected. Plants exhibiting $\mathrm{Zn}$ deficiency generally suffer severe stunting. The concentration of lead $(\mathrm{Pb})$ in waters of the inland valleys of the study area is generally low. Values ranged from 0.04 (VS2) to $0.07 \mathrm{mg} / \mathrm{l}$ (Am2). $\mathrm{Pb}$ can inhibit plant cell growth at very high concentration in soil water. The implication of the results obtained is that when farm products derived from the inland valleys of the study area are consumed, people are not likely to be exposed to food lead poisoning. The results obtained are less than $5.0 \mathrm{mg} / \mathrm{l}$ recommended by Fipps (2003) as the limit in irrigation water. The concentrations of copper $(\mathrm{Cu})$ in all the samples were below the detection level of atomic absorption spectrometry (AAS).

ANOVA results indicate that there is no significant difference in the concentration of the heavy metals analysed across the valleys $(F=2.044, p=0.138, \alpha=0.05)$. In general, most of the trace metals determined in this study have low concentrations. It can be concluded that the concentration of trace metals in the waters of the inland valleys of the study area is non-toxic to plants and the waters are suitable for irrigated agriculture. The results are comparable to those obtained in previous studies in parts of southwest Nigeria (Jaji et al. 2007; Ogunfowokan et al. 2013). For example, Ogunfowokan et al. (2013) found the overall mean levels of trace metals in three streams under 
Table 4 Summary statistics of concentration of heavy metals in sampled waters

\begin{tabular}{|c|c|c|c|c|}
\hline Index & Inland valley & Minimum & Maximum & Mean \\
\hline \multirow[t]{6}{*}{$\mathrm{Fe}(\mathrm{ppm})$} & Am1 & 0.08 & 0.10 & 0.09 \\
\hline & Am2 & 0.10 & 0.32 & 0.21 \\
\hline & VS1 & 1.77 & 8.83 & 5.70 \\
\hline & VS2 & 0.14 & 0.49 & 0.31 \\
\hline & LD1 & 0.08 & 0.11 & 0.09 \\
\hline & LD2 & 0.11 & 4.41 & 2.26 \\
\hline \multirow[t]{6}{*}{$\mathrm{Ni}(\mathrm{ppm})$} & Am1 & 0.003 & 0.01 & 0.01 \\
\hline & Am2 & 0.06 & 0.07 & 0.07 \\
\hline & VS1 & 0.02 & 0.07 & 0.04 \\
\hline & VS2 & 0.04 & 0.04 & 0.04 \\
\hline & LD1 & 0.05 & 0.05 & 0.05 \\
\hline & LD2 & 0.01 & 0.03 & 0.02 \\
\hline \multirow[t]{3}{*}{$\mathrm{Pb}(\mathrm{ppm})$} & Am2 & 0.07 & 0.07 & 0.07 \\
\hline & VS1 & 0.04 & 0.04 & 0.04 \\
\hline & LD1 & 0.05 & 0.05 & 0.05 \\
\hline \multirow[t]{6}{*}{ Zn (ppm) } & Am1 & 0.04 & 0.04 & 0.04 \\
\hline & Am2 & 0.07 & 0.08 & 0.08 \\
\hline & VS1 & 0.06 & 0.09 & 0.07 \\
\hline & VS2 & 0.04 & 0.06 & 0.05 \\
\hline & LD1 & 0.02 & 0.03 & 0.03 \\
\hline & LD2 & 0.06 & 0.08 & 0.07 \\
\hline
\end{tabular}

Sites in which the concentration of the elements is below detection level of atomic absorption spectrometry (AAS), or where samples could not be collected as a result of non-availability of water during the dry period, were not included in the table

$A m$ amphitheatre-head inland valley, $V S$ valley-side inland valley, $L D$ low-slope depression inland valley

different agricultural land systems to be $6.98,0.27,13.67$ and 0.1 for $\mathrm{Fe}, \mathrm{Ni}, \mathrm{Pb}$ and $\mathrm{Zn}$, respectively.

Table 5 shows pattern of variation of major water quality indices (SAR, SSP, TDS and PI) in water samples for the months of May 2011, September 2011, November 2011, January 2012, and March 2012. Level of concentration of sodium mineral in water is of great concern for cropping. Plants absorb sodium from soil water and transport it to leaves where it can accumulate and result in injuries to plants (e.g. foliar burning). Also, since plant leaves can directly absorb water, presence of high sodium concentration in irrigation water can be toxic to plants. Within the soil, high sodium concentration can have a more deleterious effect on soil structure. It can cause breakdown of clay particles and result in reduction of soil permeability. This is because when sodium is present in the soil in exchangeable form, it replaces calcium and magnesium adsorbed on the soil clays and causes dispersion of soil particles. A soil that disperses on wetting has a very unstable structure. It can form a surface crust or hard clods on drying. Pores below the surface can become blocked by
Table 5 Summary statistics of water quality indices of surface water of inland valleys

\begin{tabular}{llccr}
\hline Index & Inland valley & Minimum & Maximum & Mean \\
\hline SAR (meq/l) & VS2 & 0.26 & 0.98 & 0.62 \\
& LD1 & 0.12 & 1.22 & 0.67 \\
& LD2 & 0.34 & 1.70 & 0.90 \\
SSP (\%) & VS2 & 21.72 & 24.57 & 23.14 \\
& LD1 & 3.85 & 54.86 & 29.35 \\
& LD2 & 10.29 & 57.57 & 34.84 \\
TDS (mg/L) & Am1 & 19.20 & 26.24 & 23.23 \\
& Am2 & 23.36 & 24.64 & 24.00 \\
& VS1 & 55.36 & 67.52 & 58.94 \\
& VS2 & 30.40 & 41.92 & 34.05 \\
& LD1 & 24.32 & 399.36 & 153.17 \\
& LD2 & 67.20 & 125.76 & 85.76 \\
PI (meq/l) & VS2 & 1.61 & 8.02 & 4.81 \\
& LD1 & 1.34 & 10.30 & 5.82 \\
& LD2 & 1.73 & 6.00 & 3.79 \\
\hline
\end{tabular}

$A m$ amphitheatre-head inland valley, VS valley-side inland valley, LD low-slope depression inland valley

dispersed soil particles. Dispersion of soil slows down the intake of water to the root zone following rainfall or irrigation. For crops, high sodium concentrations result into problems when the infiltration rate is reduced and the crop does not have enough water available or when the hydraulic conductivity of the soil profile is too low to provide adequate drainage. SAR is used to express the relative activity of sodium ions in exchange reactions within soil (an indicator of water's likely effect on soil permeability). It is a measure of the relative concentration of sodium (detrimental element) to calcium and magnesium (beneficial elements). Soil tends to be easily cultivated and has a permeable and granular structure if calcium and magnesium are the predominant cations adsorbed on the soil exchange complex. A soil SAR $>13$ suggests a likelihood of reduced soil permeability and decreased plant survival and growth. Low values of SAR were obtained for the water samples of the six sampling sites. Mean values (in meq/l) obtained in Am, VS, and LD valley types were $0.23,0.44$ and 0.79 , respectively. Because $\mathrm{Ca}^{2+}$ was below detection level in many of the samples, particularly in Am and VS valley types, SAR could not be derived for them. However, values obtained from water sample in which $\mathrm{Ca}^{2+}$ was more than 0 were generally lower in the wet months than in the dry months. This may be due to dilution effect of rain water on the surface in stream channel. Based on the classification provided by Richards et al. ( 1954) and Fipps (2003), the values of all the surface water samples are within the excellent category (Table 2). In general, SAR values obtained from the study are comparable to 
those reported in earlier studies (Ogunfowokan et al. 2013; Talabi et al. 2014; Talabi and Tijani 2013).

The amount of soil exchange capacity occupied by sodium is usually measured as Soluble Sodium Percentage (SSP). As the SSP goes up, more exchangeable sodium is available, and the greater the potential for negative plant and soil impacts. Water consisting of high percentage of sodium may result in stunting of plants and reduces soil permeability (Joshi et al. 2009). In situations where the SSP in irrigation water is greater than $60 \%$, there may be occurrence of sodium accumulation in soil, which may induce soil deterioration and low water/oxygen permeability. The mean SSP in water samples was 21.41, 22.95 and $32.1 \%$ in Am, VS, and LD valley types, respectively. According to the classification given by Fipps (2003); Wilcox (1955), $70 \%$ of the water samples fall within excellent to good and $30 \%$ within permissible limit, with respect to usefulness for cropping (Table 2). The amount of mineral contents dissolved in water, expressed as its total dissolved solids (TDS), is important for assessing its suitability for use for various uses (Obiefuna and Sheriff 2011). Excessive concentration or short supply of dissolved solids in agricultural water may be injurious to plants. For example, high TDS may reduce plants' osmotic activities or prevent adequate soil aeration. The TDS of water samples ranged from an average of $19.2 \mathrm{mg} / \mathrm{l}$ for Am1 through $399.36 \mathrm{mg} / \mathrm{l}$ in LD1. Seasonal variation was least in Am2 valley with TDS being almost constant throughout the year, ranging from $23.68 \mathrm{mg} / \mathrm{l}$ in September to $24.66 \mathrm{mg} / \mathrm{l}$ in March. Variability was greatest in LD1 with values ranging from $24.32 \mathrm{mg} / \mathrm{l}$ in the month of September to $399.36 \mathrm{mg} / \mathrm{l}$ in the month of May. The CV indicates variable concentrations with values ranging from 0.5 to 1.36 across sites. According to the classification given by Robinove et al. (1958), the water samples were all excellent for cropping (Table 2).

Also, the mean permeability index (PI) in surface water samples (in \%) was 167.1, 125.0 and 53.8 in Am, VS, and LD valley types, respectively. According to the classification given by Doneen (1964), waters can be classified as Class I, Class II and Class III orders. Class I and Class II waters are categorized as good for irrigation with $75 \%$ PI or more. Class III water is unsuitable with $25 \%$ of maximum permeability (Naseem et al. 2010). Based on this classification, $78.57 \%$ of the water samples fall within class I and class II PI index, suggesting that groundwater of the study area is generally suitable for irrigation. This finding approximates those of Ogunfowokan et al. (2013) who found that waters of three streams of different agricultural land use systems draining southern part of the study area had PI values of more than $100 \%$.

\section{Conclusion}

The study showed that the concentrations of the major water quality parameters are generally low and are within the recommended water quality standards for agricultural utilisation. Generally, the pattern of $\mathrm{pH}$ indicated that the waters are neutral to slightly alkaline type. Low values of conductivities were recorded during the wet season and higher values in the dry season, reflecting the dilution effect of rain water during the wet months. However, values of the conductivities are within the recommended acceptable limit for cropping. The concentration of major cations varied across the inland valley types, but exhibited similar characteristics within each valley. The cationic dominance pattern is in the order of $\mathrm{Na}^{+}>\mathrm{Ca}^{2+}>$ $\mathrm{K}^{+}>\mathrm{Mg}^{2+}$. Generally, most of the physicochemical parameters and trace metals determined in this study have low concentrations and are non-toxic to plants. Values of water quality indices (sodium adsorption ratio, soluble sodium percentage, total dissolved solids and permeability index) indicated that the concentrations of minerals in waters across the valley typologies are generally within permissible limits for cropping.

Open Access This article is distributed under the terms of the Creative Commons Attribution 4.0 International License (http://creativecommons.org/licenses/by/4.0/), which permits unrestricted use, distribution, and reproduction in any medium, provided you give appropriate credit to the original author(s) and the source, provide a link to the Creative Commons license, and indicate if changes were made.

\section{References}

Aboyeji OS (2013) Characterization of inland valleys for agricultural utilization in the Derived Savanna of southwestern Nigeria. Unpublished PhD Thesis, Obafemi Awolowo University, Ile-Ife, Nigeria

Aboyeji OS, Ogunkoya OO (2014) Assessment of groundwater dynamics for agricultural use in six inland-valley agro-ecosystems of SW Nigeria. Trop Agric Trinidad 91:98-109

Andriesse W, Fresco LO, Vanduivenbooden N, Windmeijer PN (1994) Multi-scale characterization of inland valley agroecosystems in West Africa. Neth J Agric Sci 42:159-179

Awomeso JA, Gbadebo AM, Taiwo AM, Obayomi O (2010) Hydrochemical characteristics of springs in Oke-Igbo, Ondo State, Nigeria. J Appl Sci Environ Manag 14:41-45

Ayeni AO, Balogun II, Soneye ASO (2011) seasonal assessment of physicochemical concentration of polluted urban river: a case of ala river in Southwestern-Nigeria. Res J Environ Sci 5:21-33. doi:10.3923/rjes.2011.21.33

Ayers RS, Westcot DW (1994) Water quality for agriculture FAO irrigation and drainage. FAO irrigation and drainage paper no 29(1). FAO. http://www.fao.org/DOCReP/003/T0234e/T0234e 00.htm. Accessed 18 May 2015

Bauder TA, Waskom RM, Sutherland PL, Davis JG (2014) Irrigation water quality criteria. Fact Sheet No. 0.506. State University, U.S. Department of Agriculture and olorado counties 
cooperating. http://www.ext.colostate.edu/pubs/crops/00506.html. Accessed 18 April 2015

Bennett WF (1993) Nutrient deficiencies and toxicities in crop plants. APS Press, St. Paul

Buri MM, Ishida F, Kubota D, Masunaga T, Wakatsuki T (1999) Soils of flood plains of west Africa: general fertility status. Soil Sci Plant Nutr 45:37-50

Doneen LD (1964) Notes on water quality in agriculture. Department of Water, Science and Engineering, University of California, Davis, USA

Eni DI, Efiong J (2011) Seasonal variations in hydrochemical parameters of groundwater in Calabar south, Cross River State, Nigeria British. J Art Soc Sci 3:85-97

Fagbami A, Ajayi FO (1990) Valley bottom soils of the sub-humid tropical southwestern Nigeria on basement complex: characteristics and classification. Soil Sci Plant Nutr 26:179-194

Fipps G (2003) Irrigation water quality standards and salinity management strategies. Texas A\&M University. http://hdl. handle.net/1969.1/87829 Accessed 18 April 2015

Ige OO, Bale RB, Olasehinde PI (2008) Physio-chemical characteristics of water sources in Imeko, Southwestern, Nigeria. Water Res 18:32-36

Ike PC (2012) An analysis of the impact of Fadama III project on poverty alleviation in delta state, Nigeria. Asian J Agric Sci 4:158-164

Jaji MO, Bamgbose O, Odukoya OO, Arowolo TA (2007) Water quality assessment of Ogun river, South West Nigeria. Environ Monit Assess 133:473-482. doi:10.1007/s10661-006-9602-1

Joshi DM, Kumar A, Agrawal N (2009) Assessment of the irrigation water quality of River Ganga in Haridwar District India. Rasayan J Chem 2:285-292

Mukherjee S, Kumar AB, Körtvélyessy L (2005) Assessment of Groundwater Quality in the South 24-Parganas, West Bengal Coast, India. J Environ Hydrol 13 Paper 15:1-8

Naseem S, Hamza S, Bashir E (2010) Groundwater geochemistry of winder agricultural farms, Balochistan, Pakistan and assessment for irrigation water quality. Eur Water 31:21-32

Ogunremi LT, Okusami TA, Olaniyan GO, Nwankwor GI, Ogunsola OA (2000) The reconnaissance characterization of Nigerian inland valleys 73

Obiefuna GI, Sheriff A (2011) Assessment of shallow ground water quality of Pindiga Area, Yola Area, NE, Nigeria for irrigation and domestic purposes. Res J Environ Earth Sci 3:131-141

Odukoya AM, Folorunso AF, Ayolabi EA, Adeniran EA (2013) Groundwater quality and identification of hydrogeochemical processes within University of Lagos, Nigeria. J Water Resour Prot 5:930-940

Ogban PI, Babalola O (2003) Soil characteristics and constraints to crop production in inland valley bottoms in south-western Nigeria. Agric Water Manag 61:13-28

Ogban PI, Babalola O (2009) Characteristics, classification and management of inland valley bottom soils for crop production in sub-humid southwestern Nigeria. J Trop Agric Food Environ Ext $8: 1-13$

Ogunfowokan AO, Obisanya JF, Ogunkoya OO (2009) Assessment of chemical quality of three streams under different agricultural land systems in Obafemi Awolowo University Ile-Ife, Nigeria. Toxicol Environ Chem 91:847-872. doi:10.1080/027722408 02615066
Ogunfowokan AO, Obisanya JF, Ogunkoya OO (2013) Salinity and sodium hazards of three streams of different agricultural land use systems in Ile-Ife, Nigeria. Appl Water Sci 3:19-28. doi:10. 1007/s13201-012-0053-2

Ogunkoya OO, Adejuwon JO (1990) Water chemistry of some rivers draining the basement complex in southwestern Nigeria. Hydrobiol Trop 23:3-10

Page AL, Miller RH, Kenny DR (1982) Methods of soil analysis. No. 9. Part 2: chemical and microbilogical properties. American Society of Agronomy, Madison, WI, USA

Pratt PF, Suarez DL (1990) Irrigation water quality assessments. In: Tanji KK (ed) Agricultural salinity assessment and management, ACE manuals and reports on engineering practices, vol 71. ASCE, NY

Raunet M (1985) Bas-fonds et riziculture en Afrique: approche structurale comparative. Agron Trop 40:181-201

Richards LA et al. (eds) (1954) Diagnosis and Improvement of Saline and Alkali Soils. Unites States Salinity Laboratory Staff, Agriculture Handbook, vol 60. United States Department of Agriculture

Robinove CJ, Longfort RH, Brook JW (1958) Saline water resource of North Dakota vol Geological Survey Water-Supply Paper 1428. United States Government Printing Office, Washington

Talabi AO, Tijani MN (2013) Hydrochemical and stable isotopic characterization of shallow groundwater system in the crystalline basement terrain of Ekiti area, southwestern Nigeria. Appl Water Sci 3:229-245. doi:10.1007/s13201-013-0076-3

Talabi AO, Afolagboye OL, Tijani MN, Aladejana JA, Ogundana AK (2014) Hydrogeochemistry of some selected springs' waters in Ekiti Basement Complex Area, Southwestern Nigeria. Int J Eng Sci 3:19-30

Thenkabail PS, Nolte C (1995) Mapping and characterizing inland valley agroecosystems of West and Central Africa: a methodology integrating remote sensing, global positioning system, and ground - truth data in a geographic information systems framework vol RCMD monograph, vol 16. UTA, Ibadan

Thenkabail PS, Nolte C (1996) Capabilities of Landsat-5 Thematic Mapper (TM) data in regional mapping and characterization of inland valley agroecosystems in West Africa. Int J Remote Sens 17:1505-1538

Todd DK, Mays LW (2005) Groundwater hydrology, 3rd edn. Wiley and Sons Inc., New York

Wallender WW, Tanji KK (eds) (2012) ASCE manual and reports on engineering practice no. 71 agricultural salinity assessment and management, 2nd edn. American Society of Civil Engineers, Reston

WHO (2011) Guideline for drinking water quality, 4th edn. World Health Organization, Geneva

Wilcox LV (1955) Classification and use of irrigation waters vol circular, vol 696. Washington D.C

Windmeijer PN, Andriesse W (eds) (1993) Inland valleys in West Africa: an agro-ecological characterization of rice-growing environments. ILRI Publication 52. International Institute for Land Reclamation and Improvement, Wageningen, The Netherlands 